\title{
Bank lending channel of monetary policy : dynamic panel data study of Malaysia
}

\begin{abstract}
This paper aims to investigate the relevance of bank-lending channel (BLC) of monetary policy in a small-open economy, i.e. Malaysia by using disaggregated bank-level data. A dynamic panel data method namely generalized method of moments (GMM) procedure has been used in estimating the dynamic of banks' loan supply function. The empirical evidence revealed that the banks' loan supply is significantly and negatively influenced by monetary policy shocks, and therefore has supported the existence of BLC in Malaysia. Several bankcharacteristics variables namely bank liquidity and bank capitalization (capital adequacy ratio) are also statistically significant in influencing the banks' loan supply.
\end{abstract}

Keyword: Monetary policy; Bank lending channel; Dynamic panel data 